\title{
Strategy to Improve Recycling Yield of Aluminium Cans
}

\author{
Victor Yuardi Risonarta ${ }^{1}$, Juliana Anggono ${ }^{2 *}$, Yosias Michael Suhendra ${ }^{2}$, \\ Setyo Nugrowibowo ${ }^{3}$ and Yahya $\mathrm{Jani}^{4}$ \\ ${ }^{1}$ Department of Industrial Engineering, Darma Cendika Catholic University, Jl. Ir. Soekarno No. 201, \\ Surabaya 60117, Indonesia \\ ${ }^{2}$ Department of Mechanical Engineering, Petra Christian University, Jl. Siwalankerto No. 121-131, \\ Surabaya 60236, Indonesia \\ ${ }^{3}$ Walisongo Gempol School of Technology, Jl. Raya Timur Pasar No. 09, Gempol, Pasuruan 67155, \\ Indonesia \\ ${ }^{4}$ Department of Biology and Environmental Science, Linnaeus University, Stuvaregatan 4 SE-392 31 \\ Kalmar, Sweden
}

\begin{abstract}
Millions of canned drinks are consumed everyday globally and their wastes create an enviromental issue. Fortunately, the cans are made from aluminium (Al) so that it can be recycled. There are two main keypoints existing during the recycling process of $\mathrm{Al}$ cans, i.e. the aluminium loss or low Al-yield and low recycling yield. This work outlines the strategies to improve the recycling perfomance for $\mathrm{Al}$ beverage cans, i.e. by adding drossing flux, applying improved melting strategy, and cans decoating prior to melting. Drossing flux was added to assist the detachment of Al from the slag. Another improved melting strategy was worked out by decreasing exposure time cans to the furnace atmosphere during melting. All those above strategies result in an increase of recycle yield in a range of $4 \%$ to $5 \%$.
\end{abstract}

Keywords: Aluminium alloy, beverage packaging, drossing flux, melting strategy

\section{Introduction}

Aluminium is the $3^{\text {rd }}$ common used metal in the world and it is important metal for construction, automotive, airplane, and packaging industries. The construction of doors, windows, and facades, followed by walls and roofs is the main uses of aluminium in building. In automotive, aluminium is used as engine blocks, wheels, cylinder heads, gearboxes and many other automotive and engineering components. Aluminium also fits to be used as packaging of food and beverages due to its unique barrier and physical properties. Aluminium can effectively protects food and drink against the quality-reducing effects of oxygen, light, moisture, micro-organisms and unwanted aromas even in its thinnest form.

\footnotetext{
* Corresponding author: julianaa@petra.ac.id
} 
Consumption of soda and beer in aluminium cans reaches $2 \times 10^{11}$ cans every year [1]. If a can weighs $30 \times 10^{-3} \mathrm{~kg}$, thus $2 \times 10^{11}$ cans provide $6 \times 10^{9} \mathrm{~kg}$ waste every year. This leads to growing environmental concerns of which is for the aluminium industry to be in a position to continue its growth while optimising its environmental performance. Recycling activity has to be boosted in order to conserve resources and to avoid littering.

From the enviromental point of view, aluminium recycling is not only beneficial due to reduction of aluminium waste but also due to its less energy consumption and greenhouse gas emission. Moreover, primary production of aluminium from bauxite is very energy intensive with the estimated energy consumption. Secondary aluminium production through recycling consumes much less energy, i.e. only $6 \%$ of the energy consumption of primary aluminium production [2]. At present, around $1 \%$ of the man made greenhouse comes from the aluminium industry. Recycling is an essential activity of sustained aluminium use, as more than a third of all the aluminium currently produced globally originates from old, traded and new scrap [3]. The use of old scrap, i.e. scrap from end of life products, is approximately $50 \%$ of the scrap. If scrap is pre treated and/or sorted appropriately, the recycled aluminium can be utilised for almost all aluminium applications, thereby preserving raw materials and making considerable energy savings.

However, aluminium recycling experiences some challanges, i.e. aluminium oxidation which leads to aluminium loss as well as problem with purity of recycled aluminium. Carbon, silicon, and magnesium in steelmaking can be removed from liquid steel through oxygen blowing since oxidation of silicon and magnesium has more negative energy than ferrous oxidation. As a result, carbon goes to off-gas as $\mathrm{CO}$ or $\mathrm{CO}_{2}$, silicon and magnesium go to slag as $\mathrm{SiO}_{2}$ and $\mathrm{MgO}$, respectively. In contrary, alloying elements in aluminium alloy, e.g. silicon and magnesium, are difficult to be removed from aluminium alloy. If oxygen is injected into liquid aluminium alloy, aluminium oxidizes prior to oxidation of silicon and magnesium since aluminium oxidation has more negative Gibbs free energy. Aluminium loss thus occurs. Due to this circumstance, recycled aluminium tends to be used as similar products in the process. For example, recycled aluminium cans will be reused as aluminium cans as well.

To avoid oxidation of aluminium, fluxing is one of the solutions. There are several flux types are commonly used in aluminium recycling, i.e. covering flux, drossing flux, and cleaning flux $[4,5]$. Type of flux:

(i) Cover flux is used to protect surface of liquid aluminium from oxidation and hydrogen absorption.

(ii) Drossing flux is to separate trapped aluminium from oxides layer

(iii) Cleaning flux is used to clean oxides from liquid aluminium.

(iv) Furnace wall-cleaning flux prevents excessively formation of alumina on furnace wall.

In this study, drossing flux was used and its function to increase the recycling performance was evaluated.

\section{Recycling procedure}

\subsection{Chemical composition}

The beverage cans used in this study were from Sprite drink cans. The chemical composition of the can body and lid is different (Table 1). The body is made from alloy series 3104 and the lid is from 5052 [2,6]. The magnesium content in the body is higher than in recycled cans lid can be reused as cans lid material while cans body can be reused as cans body material. 
Table 1. Chemical composition of cans body and lid.

\begin{tabular}{lcccc}
\hline Part & Al & $\mathrm{Mg}$ & $\begin{array}{c}\mathrm{Mn} \\
{[\text { wt. \% ] }}\end{array}$ & $\mathrm{Fe}$ \\
\hline \multicolumn{5}{c}{ Studied sample } \\
\hline Body & 93.75 & 4.82 & 0.27 & 0.26 \\
Lid & 96.46 & 2.53 & 0.33 & 0.32 \\
\hline \multicolumn{5}{c}{ From reference $[2,6]$} \\
\hline Body & 95.20 & 0.80 to 1.30 & 0.80 to 1.40 & 0.80 \\
Lid & 97.80 & 2.20 to 2.80 & 0.10 & 0.40 \\
\hline
\end{tabular}

\subsection{Melting preparation}

Prior to melting, cans are decoated since decoated can since preliminary research work shows that decoated cans were predicted to deliver higher recycling yield higher compared to coated cans [7]. After decoating, the cans body and lid are separated. The cans body were prepared into two different forms; first one was by squashing them into thin products (approximately $0.03 \mathrm{~m}$ high) and second form was sectioning them into small pieces of $0.02 \mathrm{~m} \times 0.02 \mathrm{~m}$. Those forms were chosen to accelerate the melting process by shortening the contact duration between cans body and furnace atmosphere which results in less aluminum oxidation.

\subsection{Crucible coating}

To prevent iron diffusion to the aluminium melt, the inner wall of the steel crucible used in this work was coated prior to melting process (Figure 1). Iron diffusion to the aluminium should be prevented since iron deteriorates mechanical properties of aluminium alloys [3].

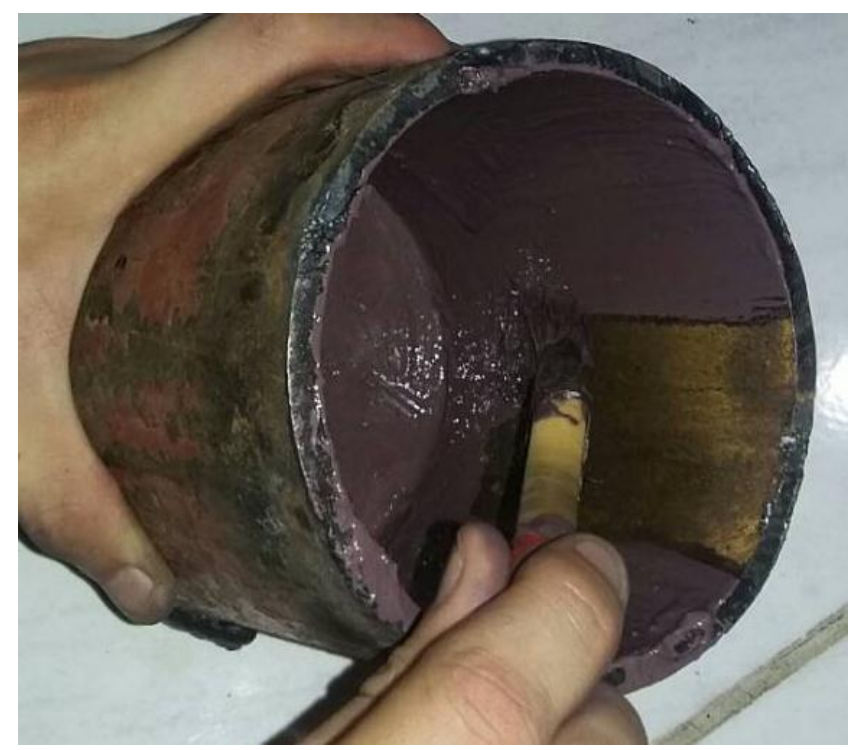

Fig. 1. Steel crucible coating. 


\subsection{Melting process}

Melting of aluminium cans was worked out in an electric resistance furnace. The furnace temperature was set at $1033.15 \mathrm{~K}$. In this work, melting strategy used was creating hot heel of aluminium by melting the squashed body at first step. After that, the $0.02 \mathrm{~m} \times 0.02 \mathrm{~m}$ aluminium sheets can be directly immersed in the hot heel when the molten aluminium (hot heel) is already available. This strategy was conducted to decrease contact duration between the cans and furnace atmosphere in order to prevent the aluminium oxidation in solid-state at temperature between $902.15 \mathrm{~K}$ and $923.15 \mathrm{~K}$ [8]. The formation of $\mathrm{Al}_{2} \mathrm{O}_{3}$ at temperature below melting temperature delivers difficulty since melting point of $\mathrm{Al}_{2} \mathrm{O}_{3}$ is $2303.15 \mathrm{~K}$ which consumes very high energy to melt. For each experimental condition (Table 2), total aluminium cans used were $0.44 \mathrm{~kg}$. Body or lid was charged into the furnace as three consecutive charges.

Table 2. Experiment condition in this work.

\begin{tabular}{cccc}
\hline Experiment & Cans part & Decoating & Flux \\
\hline 1 & Lid & Yes & No \\
2 & Lid & Yes & Yes \\
3 & Body & Yes & No \\
4 & Body & Yes & Yes \\
5 & Body & No & Yes \\
\hline
\end{tabular}

Meanwhile, the use of flux followed a particular procedure: $1 \times 10^{-3} \mathrm{~kg}$ of flux containing $\mathrm{NaCl}$ and $\mathrm{KCl}$ was charged into the molten aluminium in three consecutive stages. The first flux was charged soon after the batch completely melted. The second charge was given after the last aluminum batch melted. Finally, the last one was charged afterward and the molten aluminium was put in hold for $6 \times 10^{2} \mathrm{~s}$.

\section{Result and discussion}

\subsection{Influence of drossing flux}
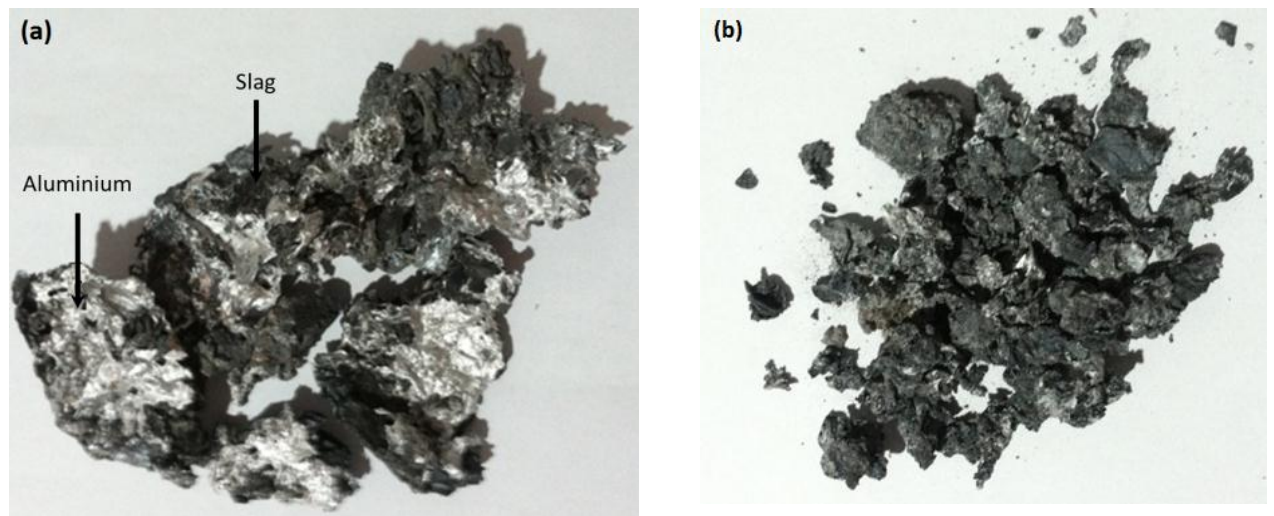

Fig. 2. Slag without drossing flux (a) and with drossing flux (b).

From the experiment 1 and experiment 3, it was observed from the slag without drossing flux that some aluminium were adhered to the slag (Figure 2). The presence of this aluminium in slag leads to reduction of aluminium content in the melt. It can be seen on the photograph of the slag that the metallic (shiny) parts on the slag surface representing quite 
significant amount the free aluminium in the slag. On the other hand, slag formation in experiment 2, exp. 4, and exp. 5 (with flux addition) shows almost no free aluminium sticking on the slag. Additionally, pouring of molten aluminium to cast the samples was easier when drossing flux was used. This leads to shorten tap to tap time which improves recycling productivity.

\subsection{Recycling yield}

Recycling yield (Yield Recycle $_{\text {) }}$ in this work is defined as the ratio of total metal mass after melting $\left(\mathrm{m}_{\text {tap }}\right)$ compared with the input mass of aluminium cans $\left(\mathrm{m}_{\text {Cans,total }}\right)($ Eq. 1).

$$
\text { Yield }_{\text {Recyxle }}=\frac{m_{\text {tap }}}{m_{\text {Cans,total }}}
$$

Cans recycling with drossing flux shows higher recycling yield (55.2\% to $59.1 \%)$ than recycling without flux use $(52.5 \%$ to $54.7 \%$ ) (Table 3$)$. Drossing flux increases the recycling yield of cans body $5 \%$ higher than the yield obtained without drossing flux. The recycling yield of lid using drossing flux was also improved by $4.4 \%$ higher compared with the process without drossing flux. Pirker et al. [9] also reported that $\mathrm{NaCl}$ and $\mathrm{KCl}$ increase recycle yield.

Table 3. Cans mass before and after recycling.

\begin{tabular}{|c|c|c|c|}
\hline \multirow{2}{*}{ Experiment } & $\mathbf{m}_{\text {Cans,total }}$ & $\mathbf{m}_{\text {tap }}$ & Yield \\
\hline & \multicolumn{2}{|c|}{$\frac{m_{\text {Cans,total }} \mathrm{m}_{\text {tap }}}{[\mathrm{kg}]}$} & {$[\%]$} \\
\hline 1 & 0.44 & 0.231 & 52.5 \\
\hline 2 & 0.44 & 0.251 & 57.5 \\
\hline 3 & 0.44 & 0.241 & 54.7 \\
\hline 4 & 0.44 & 0.26 & 59.1 \\
\hline 5 & 0.44 & 0.243 & 55.2 \\
\hline
\end{tabular}

Meanwhile, decoating process performed on cans body was beneficial for improving the recycling yield. This strategy increased recycling yield by approximately $4 \%$ higher than coated cans body. The coating used was made of inorganic pigment [10]. Exemplary pigments used in coating are titanium oxide $\left(\mathrm{TiO}_{2}\right)$, chromium oxide $\left(\mathrm{Cr}_{2} \mathrm{O}_{3}\right), \mathrm{ZnCrO}_{4}$ or iron oxides $\left(\mathrm{FeO}, \mathrm{Fe}_{2} \mathrm{O}_{3}, \mathrm{Fe}_{3} \mathrm{O}_{4}\right.$ ) (Table 4). Gibbs free energy of these oxides formation is more positive than the formation of aluminium oxide $\left(\mathrm{Al}_{2} \mathrm{O}_{3}\right)$. The Ellingham Diagram informs that oxides of other elements with less negative Gibbs energy, e.g. $\mathrm{TiO}_{2}, \mathrm{FeO}$, $\mathrm{Cr}_{2} \mathrm{O}_{3}$, transfer its oxygen to pure aluminium and creates $\mathrm{Al}_{2} \mathrm{O}_{3}$. This causes aluminium loss. Exemplary reactions causing aluminum loss are presented in Eq. 2 to Eq. 6.

$$
\begin{gathered}
2 / 3 \mathrm{TiO}_{2}+2 \mathrm{Al}=\mathrm{Al}_{2} \mathrm{O}_{3}+\mathrm{Ti} \\
3 \mathrm{FeO}+2 \mathrm{Al}=\mathrm{Al}_{2} \mathrm{O}_{3}+3 \mathrm{Fe} \\
\mathrm{Fe}_{2} \mathrm{O}_{3}+2 \mathrm{Al}=\mathrm{Al}_{2} \mathrm{O}_{3}+2 \mathrm{Fe} \\
\mathrm{Fe}_{3} \mathrm{O}_{4}+8 / 3 \mathrm{Al}=4 / 3 \mathrm{Al}_{2} \mathrm{O}_{3}+3 \mathrm{Fe} \\
\mathrm{Cr}_{2} \mathrm{O}_{3}+2 \mathrm{Al}=\mathrm{Al}_{2} \mathrm{O}_{3}+2 \mathrm{Cr}
\end{gathered}
$$


Table 4. Inorganic substance used as coating pigment [10].

\begin{tabular}{lll}
\hline \multicolumn{1}{c}{ Substance } & \multicolumn{1}{c}{ Chemical formula } & \multicolumn{1}{c}{ Colour } \\
\hline Titanium dioxide & $\mathrm{TiO}_{2}$ & White \\
Ferrous oxides & $\mathrm{FeO}_{2}, \mathrm{Fe}_{2} \mathrm{O}_{3}, \mathrm{Fe}_{3} \mathrm{O}_{4}$ & yellow, red, brown, black \\
Chromium oxides & $\mathrm{Cr}_{2} \mathrm{O}_{3}$ & green, blue \\
Zinc chromates & $\mathrm{ZnCrO}_{4}$ & Yellow \\
Carbon black & $\mathrm{C}$ & Black \\
Azurite & $\mathrm{Cu}_{3}\left(\mathrm{CO}_{3}\right)_{2}(\mathrm{OH})_{2}$ & Blue \\
\hline
\end{tabular}

\subsection{Chemical composition after recycling}

Meanwhile, aluminium yield $\left(\mathrm{Yield}_{\mathrm{Al}}\right)$ is defined as the ratio of aluminium mass after melting $\left(\mathrm{m}_{\mathrm{Al} \text {,tap }}\right)$ compared to the input mass of aluminium $\left(\mathrm{m}_{\mathrm{Al}, \mathrm{i}}\right)$ (Eq. 7). The input mass of aluminium depends on each aluminium weight percent $\left(\mathrm{x}_{\mathrm{Al}, \mathrm{i}}\right)$ in cans body and lid (Eq. 8 and Eq. 9)

$$
\begin{gathered}
\text { Yield }{ }_{A l, i}=\frac{m_{A l, t a p}}{m_{A l, i}} \\
\mathrm{~m}_{\mathrm{Al}, \mathrm{body}}=\mathrm{x}_{\mathrm{Al}, \mathrm{i}} \mathrm{m}_{\mathrm{i}} \\
\mathrm{m}_{\mathrm{Al}, \mathrm{lid}}=\mathrm{x}_{\mathrm{Al}, \mathrm{i}} \mathrm{m}_{\mathrm{i}}
\end{gathered}
$$

Where $\mathrm{i}=$ cans body or cans lid

Aluminium concentration after recycling of cans lid is higher than initial aluminium of cans lid (Table 5). Similar finding was identified with the aluminium content of recycling the cans body (Table 6). On the other hand, magnesium concentration after recycling of cans lid is slightly lower than the initial magnesium concentration. This condition occurs also on the recycling of cans body. In the Ellingham Diagram, magnesium oxidation shows more negative Gibbs free energy than aluminium oxidation. Thus, magnesium is more easily oxidized by the furnace atmosphere and also by oxides of other elements including $\mathrm{Al}_{2} \mathrm{O}_{3}$. Thus, the oxidized aluminium, both by furnace atmosphere and other oxides, may transfer its oxygen to magnesium resulting in magnesium loss. Exemplary reactions resulting magnesium loss are presented in Eq. 10 to Eq. 13.

$$
\begin{aligned}
\mathrm{TiO}_{2}+2 \mathrm{Mg} & =2 \mathrm{MgO}+\mathrm{Ti} \\
\mathrm{FeO}+\mathrm{Mg} & =\mathrm{MgO}+\mathrm{Fe} \\
\mathrm{Cr}_{2} \mathrm{O}_{3}+3 \mathrm{Mg} & =3 \mathrm{MgO}+2 \mathrm{Cr} \\
\mathrm{Al}_{2} \mathrm{O}_{3}+3 \mathrm{Mg} & =3 \mathrm{MgO}+2 \mathrm{Al}
\end{aligned}
$$

Tabel 5. Chemical composition of cans lid before and after recycling

\begin{tabular}{ccccc}
\hline \multirow{2}{*}{ Experiment } & Al & Mg & Mn & Fe \\
\cline { 2 - 5 } & \multicolumn{4}{c}{ [wt. $\%$ ] } \\
\hline Initial & 93.75 & 4.82 & 0.27 & 0.26 \\
1 & 96.46 & 2.53 & 0.33 & 0.32 \\
2 & 96.27 & 2.78 & 0.39 & 0.31 \\
\hline
\end{tabular}


Tabel 6. Chemical composition of cans body before and after recycling

\begin{tabular}{|c|c|c|c|c|}
\hline Experiment & Al & $\begin{array}{c}\text { Mg } \\
\text { [wt. }\end{array}$ & $\underset{\%]}{\mathbf{M n}}$ & $\mathbf{F e}$ \\
\hline Initial & 96.61 & 1.21 & 0.73 & 0.69 \\
\hline 3 & 97.19 & 0.95 & 0.63 & 0.58 \\
\hline 4 & 97.28 & 0.83 & 0.66 & 0.57 \\
\hline
\end{tabular}

\section{Conclusion}

Recycling is a key element for sustainable aluminium consumption. Besides reducing the amount of aluminum waste, aluminium recycling also delivers environmental benefit since aluminum recycling requires only $5 \%$ of energy consumption of primary aluminum production. Strategies to improved aluminium recycling have been outlined in this work. Using of drossing flux increases recycling yield by $5 \%$. Due to thermal energy provided by exothermic reaction between drossing flux and aluminium metal sticking to slag, the slag temperature increases. This circumstance enables the sticking aluminium to detach from the slag. Additionally, de-coating of cans body can increase yield of aluminium recycling by $4 \%$. The coating contains inorganic pigments, such as $\mathrm{Cr}_{2} \mathrm{O}_{3}$ and $\mathrm{TiO}_{2}$. They oxidize aluminium to form slag and this circumstance causes aluminium loss.

\section{Reference}

1. The World Counts. We use a lot of aluminium. [Online] from http://www.theworldcounts.com/counters/world food_consumption_statistics/alumini um cans facts. (2014) [Accessed on 24 June 2018].

2. OECD global forum on environment focusing on sustainable materials management .p. 36-37 [Online] from http://www.oecd.org/environment/waste/46194971.pdf [Accessed on 1 June 2019].

3. R. Lumley. Fundamentals of aluminium metallurgy: Production, processing and applications. Sawston: Woodhead Publishing (2010). p. 71-73.

https://www.elsevier.com/books/fundamentals-of-aluminium-metallurgy/lumley/9781-84569-654-2

4. K.J. Friesen, T.A. Utigard. Coalescence behaviour of aluminum droplets under a molten salt flux cover, Light Metals (1997). p. 857-864. [Online] from https://www.researchgate.net/publication/289257624_Coalescence_behaviour_of_alu minum_droplets under_a molten_salt flux cover [Accessed on 1 June 2019].

5. R. Gallo, D. Neff. Aluminum fluxes and fluxing practice. In ASM handbook volume 15 - casting. Ohio: ASM International (2008). p. 230-239.

https://app.knovel.com/web/toc.v/cid:kpASMHVC04/viewerType:toc/

6. United aluminum. Chemical composition and properties of aluminum alloys. [Online] from https://www.unitedaluminum.com/chemical-composition-and-properties-ofaluminum-alloys/. (2013) [Accessed on 24 June 2018].

7. P.A. Soetjipto, J.Anggono, V.Y. Risonarta. Studi pengaruh cat serta pemisahan tutup dan badan kaleng minuman dalam proses peleburan pada kadar aluminium. [The effect of paint and the separation of lids and beverage can bodies during melting process on the aluminium content], Mechanova Vol. 6. p. 1-4 (2017) [Online] from http://publication.petra.ac.id/index.php/teknik-mesin/article/viewFile/6879/6238 [Accessed on 1 June 2019] [in Bahasa Indonesia].

8. J. Anggono. The influence of the morphology and size of aluminium powders on their oxidation behaviour. In I. G. Antara, N. M. Dwidiani, A. Ghurri, \& I. G. Karohika 
(Eds.). Prosiding Seminar Nasional Tahunan Teknik Mesin IV, (Bali, Indonesia, 2005). Prosiding SNTTM 4:135-139(2005).

https://www.researchgate.net/publication/43800802 The Influence_of the Morpholo gy and Size of Alumnium_Powders on Their_Oxidation_Behaviour

9. A. Pirker, H. Antrekowitsch, W. Fragner, H. Suppan, and M. Kettner. BHM Berg- und Hüttenmännische Monatshefte, 160, 7:320-327(2015).

https://www.researchgate.net/publication/282540054_Optimization of the Alrecycling Process for_Low Grade Scraps

10. J. Lakind. Can coatings for foods and beverages: Issues and options. International Journal of Technology Policy and Management. 13. 80. 10.1504/IJTPM.2013.050999. [Online] from https://www.researchgate.net/publication/258109975_Can_coatings_for_foods_and_b everages_Issues_and_options. (2013). [Accessed on 1 June 2019]. 